\title{
Connecting People, Trade and Orders of Knowledge The Mediality and Intermediality of Early Modern Auction Catalogues
}

\author{
ELIZABETH HARDING
}

Herzog August Bibliothek

Auction catalogues have received a fair amount of attention over the last couple of years. On a digital level, this interest is evident in a variety of databases, such as the Art Sales Catalogues Online 1600-1900 (ASCO), the Book Sales Catalogues Online (BSCO), the German Sales Catalogs and the Getty Provenance Index databases. Indeed, they are useful sources in different research contexts: for constructing the ownership history of objects (provenance); for developing local, national and global collection profiles (trade routes and tastes); for reconstructing prices (markets); and, especially in the context of book history, for studying the dissemination of ideas through text (enlightenment). ${ }^{1}$ Though at a first glance they may appear diverse, these approaches mainly centre on the information the auction catalogues provide about the trade objects that are being sold - be they books, art works or other trade goods. Despite the considerable scholarship they have attracted and the social and cultural importance which is attributed to them, it is only recently that research has begun to develop methods to deal with the use of auction catalogues and their agency. ${ }^{2}$

1 Alicia Montoya, 'The MEDIATE project,' Jaarboek voor Nederlandse Boekgeschiedenis / Yearbook for Dutch Book History 25 (2018): 229-32; SUSANNA AVERY-QUASH and CHRISTIAN HUEMER, eds, London and the Emergence of a European Art Market, 1780-1820 (Los Angeles: The Getty Research Institute, 2019); BERT DE MUNCK and Dries LyNA, eds, Concepts of Value in European Material Culture, 1500-1900 (Farnham: Ashgate Publishing Company, 2015); NeIL DE MARCHI and SophIE RAuX, eds, Moving Pictures: Intra-European Trade in Images, 16th to 18th Centuries (Turnhout: Brepols, 2014); DRIES LYNA et al., eds, Art Auctions and Dealers. The Dissemination of Netherlandish Painting During the Ancien Régime (Turnhout: Brepols, 2009); JEREMY WARREN and ADrianA Turpin, eds, Auctions, Agents and Dealers: The Mechanisms of the Art Market 1660-1830 (Oxford: Beazley Archive, 2007); BRUNO BLONDÉ et al., eds, Buyers and Sellers. Retail Circuits and Practices in Medieval and Early Modern Europe (Turnhout: Brepols, 2006); John Michael Montias, Art at Auction in 17th century Amsterdam (Amsterdam: Amsterdam University Press, 2002). For the German context see also THOMAS KETELSEN and TilmanN VON STOCKHAUSEN, 'Einleitung,' in Verzeichnis der verkauften Gemälde im deutschsprachigen Raum vor 1800, Vol. 1 (a-bi), eds ThOMAs KeTELSEN and Tilmann vON StOCKHAusen (Munich: Saur, 2002), 11-40 and REINHARD WITTMANN, ed., Bücherkataloge als buchgeschichtliche Quellen in der frühen Neuzeit (Wiesbaden: Harrassowitz, 1984).

${ }^{2}$ From the perspective of art history: DrIES LYNA, 'Words of Value? Art Auctions and Semiotic Socialization in the Austrian Netherlands (1750-1794),' in Concepts of Value in European Material Culture, 1500-1900, eds BERT DE MUNCK and DRIES LYNA (Farnham: Ashgate Publishing Company, 2015), $57-$ 73; SophIE Raux, 'From Mariette to Joullain: Provenance and Value in Eighteenth-Century French Auction Catalogs,' in Provenance: An Alternate History of Art, eds Gail FeIGENBAum and Inge ReIsT (Los Angeles, CA: Getty Publications, 2012), 88-105; Tillmann vON STOCKHAUSEN, 'Formen des Ordnens. Auktionskataloge des 18. Jahrhunderts als Beginn der modernen Kunstgeschichte,' in Räume der Kunst. Blicke auf Goethes Sammlungen, eds MARKuS BERTSCH and JOHANNES GRAVE (Göttingen:

Cromohs (Cyber Review of Modern Historiography), ISSN 1123-7023, 23/2020

(C) 2020 The Authors. This is an open access article published by Firenze University Press under the terms of the Creative Commons Attribution Licence, which permits use, distribution and reproduction in any medium, provided the original work is properly cited

DOI: $10.36253 /$ cromohs-12075 
How do these paper-based objects function as mediators of things? How do they present, order and classify them? And even more fundamentally: What role do they play in the actual auction? How do they structure trade and facilitate it? How are these fascinating orders of knowledge that reflect understandings of early modern objects rooted in social interaction?

After a brief introduction on the current trends in historiography on auction catalogues (par. 'Current State of Research and the Art of the List'), this contribution aims to highlight the objects' potential for research on (inter)mediality, trade and orders of knowledge from a praxeological perspective (par. 'The Mediality of Auction Catalogues'). In a case study, it explores the material traces and the listing of prices and buyers as a note-taking practice which, like the catalogues themselves, facilitated social interaction and advanced knowledge (par. 'Interleaved Auction Catalogues'). We will only be able to fully understand the epistemic and social relevance of auction catalogues by including an approach that focuses on the social context at which they were aimed (the commercial, open-spectacle 'auction').

This study focuses on one national context, namely Germany, as there were different normative frameworks for conducting auctions in Europe. Nevertheless, with all the necessary caution, findings from other countries are also included. The article mainly builds on historians' ongoing interest in reception studies and book culture. Hence, though the principal focus is on book auction catalogues, the study attempts to raise questions relevant to other disciplines too.

\section{Current State of Research and the Art of the List}

As the aforementioned databases testify, the editors of auction catalogues have often equated them with other object lists, such as stock or sales catalogues or (probate) inventories, thereby paying scant regard to the different communicative settings in which these sources were created. ${ }^{3}$ To be sure, such sources were of a highly permeable nature, as Helwi Blom, Rindert Jagersma and Juliette Reboul have recently convincingly argued with regard to book lists. ${ }^{4}$ While focusing on book lists as a whole, these scholars, members of the MEDIATE big data project, provide a useful specification of the qualities of book catalogues. In their book, the authors list the sheer number of catalogues, their accessibility, the wealth of information provided (with regard to what they tell us about a collection), their high level of bibliographical detail, their relevance for the book trade (networks), the information they offer on prices and buyers, and the information they contain about the books' use (marginalia). ${ }^{5}$ However, despite their aim to reassess the history of book lists as a whole, Blom,

Vandenhoeck \& Ruprecht, 2005), 89-101; CYNTHIA WALL, 'The English Auction, Narratives and Dismantlings,' Eighteenth Century Studies 31 (1997): 1-25. From the perspective of book history: HELWI Blom, Rindert Jagersma and Juliette Reboul, 'Printed Private Library Catalogues as a Source for the History of Reading in Seventeenth- and Eighteenth-Century Europe,' in The Edinburgh History of Reading: 1. Early Readers, ed. MARY HAMmOND (Edinburgh: Edinburgh University Press, 2020), 249-69.

3 This is the case regarding both book and art sales projects.

${ }^{4}$ Blom, Jagersma and Reboul, 'Printed Private Library Catalogues.'

${ }^{5}$ Blom, Jagersma and Reboul, 'Printed Private Library Catalogues,' $257 \mathrm{f}$. 
Jagersma and Reboul only hint at the communicative situation that produced the lists, which they in turn influenced.

However, a better understanding of the ways in which lists were used in social interaction opens up avenues of inquiry on how this interplay of text and communication formed orders of knowledge in general. Where previous research has focused on the objects marketed by lists, such an approach addresses the list itself (the list as an object), in three ways: First, in line with the more recent approaches in book history, it aims to investigate the specific nature of the medium in question, its properties, composition and materiality. ${ }^{6}$ Secondly, regarding the actual text, this perspective attempts to analyse its history (the sources it was based upon and the toolkit its writers used). This includes, for example, recognising templates and intertextual and intermedial 'translations' and principles of referencing and citation, and analysing their significance not just for reception in general but also for how people interacted as a result. Thirdly, and this is the key aim of my paper, it is important to establish the ways in which media are used: research on the cultural history of early modern politics has shown that objects, such as clothing, coats of arms and codices, were employed to empower political-social order. As political order was not anchored in a written constitution (or only to a very limited extent), these media contributed to stabilising societies. Thus, such an exploration of how an object is used in social interaction may open up perspectives on how to better understand the effect that catalogues had on the political dimension of communication (as a socially stabilising or destabilising medium). ${ }^{7}$

This essay briefly outlines a threefold framework for an approach to the medial properties of auction catalogues and the specific ways in which they were rooted in and shaped social interaction. It will then discuss a particular sort of object list - the interleaved copy - and its various links to the 'auction' as an open, not socially exclusive communicative event.

\section{The Mediality of Auction Catalogues}

\section{Fiction of Presence}

It is hardly surprising that auction catalogues had print runs of up to 400 copies, usually in a handy quarto or octave format, given their function as marketing instruments: as

\footnotetext{
${ }^{6}$ Recent publications include: Anthony Grafton, Inky Fingers: The Making of Books in Early Modern Europe, (Cambridge, MA and London: Harvard University Press, 2020); JORDAN AlEXANDER STEIN, When Novels Were Books (Cambridge, MA and London: Harvard University Press, 2020); DANIEL Bellingradt et al., eds, Books in Motion in Early Modern Europe. Beyond Production, Circulation, and Consumption (Cham: Palgrave Macmillan, 2017); for the German context UTE SCHNEIDER, ed., Praxeologische Studien zur historischen Buchwissenschaft (Wiesbaden: Harrassowitz, 2019). On object lists in particular: MAlCOLM WalsBY, 'Book Lists and Their Meaning,' in Documenting the Early Modern Book World: Inventories and Catalogues in Manuscript and Print, ed. Malcolm WalsBy and Natasha CONSTANTINIDOU (Brill: Leiden, 2013), 1-24.

7 For example, Findlen, Objects. On clothing: Ulinka Rublack, Dressing Up: Cultural Identity in Renaissance Europe (Oxford: Oxford University Press, 2010); for the German context, more generally, Marian FÜsSEL, 'Die Materialität der Frühen Neuzeit. Neuere Forschungen zur Geschichte der materiellen Kultur,' Zeitschrift für Historische Forschung 42 (2015): 433-63.
} 
cheap or, more often, complimentary objects, they reached a larger, more distant audience than any sort of verbal communication could. What is perhaps a little more surprising in view of this function is that, especially in the early stages of the history of auction catalogues, in many catalogues the entries are extremely vague and so they are now often difficult to decipher. The catalogue authors bundled the information they provided on each object into short descriptions, rarely more than one or two lines long, with abbreviations and other short forms. ${ }^{8}$ In many cases, the temptation is to believe that catalogue authors had little interest in an in-depth description of the materiality of an object and/or its size, form, origin or iconographic components.

However, it is important to look beyond the individual, isolated print material, as these sources gained their significance from the wider context and the social setting in which they were used: for instance, it is well known that scholars, aristocrats and other patrons collected them and discussed their content as an important source of information on objects, collections and collectors. Using the example of catalogues from early seventeenth-century Leuven, David McKitterick argues that the texts explicitly encouraged their readers to distribute them, while linking their minimalist nature - ' $[\mathrm{t}]$ here were no details of place or date of publication, and older books were mixed with more recent ones. The same was mostly true for other early Leuven auction catalogues. It remained true on occasion even a hundred years later' - to the fact that ' $[t]$ hese were sales in a close-knit university community, addressed to local audiences, most of whom could be assumed to have some connection with the university .... There was no call for unnecessary detail. ${ }^{9}$ In other words, the catalogues provided very little information on the objects and it could only be fully understood with the help of others (collectors, agents or other auction attendees).

However, auctioneers traded objects and wanted to make money from them. Their aim was to attract a large number of buyers. The catalogues therefore explicitly asked their readers to circulate the texts. In this way, they targeted a broad market that reached beyond the immediate community. An auction catalogue from 1744 for the book collection of the lawyer Johann Paul Kress gives some measure of this business. It names 27 contact persons, from Augsburg and Göttingen to Berlin, who were willing to distribute it. David McKitterick describes the case of an English book auction of $1687-88$, where the list of booksellers offering to circulate the catalogue included names from Amsterdam, Brussels, Paris and Cologne. ${ }^{10}$

\footnotetext{
8 They are, in this sense, very similar to other book or collection catalogues and inventories (both important models/sources for auction catalogues). On these see WALSBY, 'Book Lists'; GIORGIO RIELLO, 'Things Seen and Unseen: The Material Culture of Early Modern Inventories and Their Representation of Domestic Interiors,' in Early Modern Things: Objects and their Histories, 1500-1800, ed. PAula Findlen (London; New York: Routledge, 2013), 125-50; JessiCa KEATING and Lia Markey, 'Introduction. Captured Objects: Inventories of Early Modern Collections,' Journal of the History of Collections 23 (2011): 209-13.

9 David McKitTerick, The Invention of Rare Books. Private Interest and Public Memory, 1600-1840 (Cambridge, UK and New York: Cambridge University Press, 2018), 112.

10 MCKITTERICK, The Invention of Rare Books, 117.
} 


\title{
Эerzei einer
}

\section{aนตือtiefenen Sammlung}

bon

Saturalient und Siutifiachent,

auch) phyfitearifichen Inffrumenten,

\author{
nebft einer \\ Tabelle und Ertlairung
}

Sartinifben Siondbylienfiftems.

(2)

Diefe Sammilung wirb ben r 3 . Decemb. uns folgende ₹age burd, ben 2futtionetommiffas

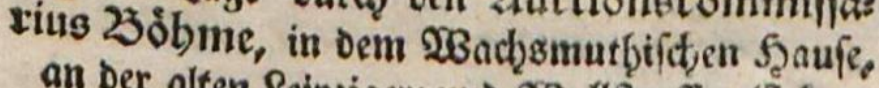

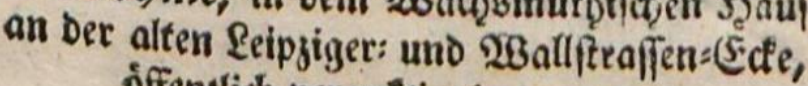
offentlich verauftioniret weroen.

Das . Berzecibnis wiro begm 2huftionsfonmiffarius

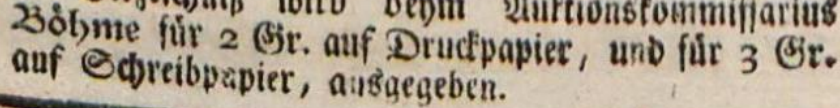

Beerlin,
gebsude mit ミoffef

Figure 1: Front page of an auction catalogue: information on the distributor. University and State Library Saxony-Anhalt, Ub Halle, Zweigbibliothek Europäische Aufklärung, Friedrich Martini, Verzeichniß einer auserlesenen Sammlung von Naturalien und Kunstsachen (Berlin: Bosse, 1773), Pa 2297, http://digitale.bibliothek.uni-halle.de/vd18/content/pageview/3754997. 
In his analysis of the history of auction catalogues, McKitterick argues that the catalogues were originally addressed to a very geographically limited audience only. However, when the auction market expanded during the early modern period, the auctioneers responded to the growing need to provide more information by developing new, more detailed object description methods. In other words, catalogues increasingly replaced face-to-face communication among peers and adapted to a growing, increasingly diversified market. ${ }^{11}$

It is plausible that the auctioneers were responding to the boom in consumers at eighteenth-century auctions (during the so-called 'consumer revolution'). Yet, it does not explain why such minimalist catalogues, though in smaller numbers, were still circulating in the eighteenth century. As far as auctions of individuals' 'private' collections are concerned (as opposed to trade stock auctions), the persistence of seemingly careless listing practices can also be explained by the way the collection was intended to be publicised: as documentation of what the collection or household looked like before its dissolution (i.e., due to death, a change of residence or insolvency) and how it was encountered by the people who wrote the inventory report. Indeed, some auction catalogues, such as probate inventories, might have originally served legal purposes and might only have been turned into an auction catalogue later on. ${ }^{12}$ This can explain why auction catalogues look a lot like inventories and why many catalogues contain chapter sections that more or less explicitly give the impression that the items are mentioned in a given spatial order. ${ }^{13}$

This order was functional, not only for inventories: booksellers and other auctioneers were known to replace objects with others or to add further items from their own holdings to supposedly closed collections, a practice that was detrimental to consumer interests and therefore repeatedly met with legal restrictions. The minimalist way in which the auction catalogues referred to the objects made the texts appear an authorised, credible record of what the salesman had found there on the day he was asked to sell the collection; a text created on the spot and in the house where the collection had previously been assembled. ${ }^{14}$ The description was a way of guaranteeing that no item had been removed or added since the collector had died, moved away or become insolvent, and that there could be no doubt about the provenance. The auction catalogue is thus a medium that closes a spatial and temporal distance (between the inventorying of the collection and the reading of the catalogue) by trying to appear as

${ }^{11}$ MCKITTERICK, The Invention of Rare Books, 112.

12 Blom, Jagersma and Reboul, 'Printed Private Library Catalogues,' 252.

13 On inventories: Riello, 'Things Seen and Unseen'; Jessica Keating and Lia Markey, 'Introduction.'

${ }^{14}$ On the epistemic links between catalogues and inventories see also JÖRN MÜNKNER, 'Papierstauraum: Bücher und Objekte in Katalogen,' Neohelicon 47 (2020): 393-408. 
close to the (supposed) event as possible. In other words: the object list bridged the distance through the fiction of presence. ${ }^{15}$

\section{Normative Text and Performative Materiality}

Early modern auction catalogues raise many unanswered questions in terms of their significance for auctions: Were the catalogues used at auctions and did they determine the behaviour of the audiences there? If so, how did their significance in terms of their presence relate to the role of the auctioneers and bidders? What part did the written content (the information they provided) play in the process? How, for instance, did it affect the oral presentation? Did the auctioneers, for example, give a 'lecture' on the objects, by reading out the written object descriptions word by word? Or was it a 'translation' of the text more specifically addressed to the face-to-face situation? With regard to one of the most prominent figures in the history of auctions, James Christie, it has been suggested that an auctioneer's success lay in his oral strategy and ability to seduce the audience and evoke intense emotions - but what did that mean for the catalogue, how far could an auctioneer go with such marketing methods? ${ }^{16}$

Today, catalogues usually serve as a script for the auction, and auctioneers present the items according to the given order of lots. The text defines the temporal structure of the auction business, allowing the bidders to decide whether or not to take part in the whole auction. Also, when attending an auction, buyers can link the textual information on a respective lot number directly to the actual object. In contrast, bidders who attend auctions where the auctioneer deviates from the given order have much more preparation work to do should they wish to compare the lot numbers with the objects.

While this practice is common today, in the early modern period, the catalogue and the auction were less tightly connected to each other: However, so-called interleaved catalogues for eighteenth-century book auctions suggest that catalogues were at least relevant in this context. Interleaved works contain an additional blank page bound in after each printed page. In the case of auction catalogues, these sheets were included to document the respective prices for which the objects were bought. This practice of keeping note of prices, which will be discussed in the next paragraph in more detail, relies on auctioneers calling the lot numbers out in the order given in the catalogue.

Besides this, laws that were imposed on auctions in the eighteenth century, including paragraphs on the catalogues, suggest that they served as 'scripts' for interaction. These determined that catalogues had to contain lot numbers and that the order of the lots had to be followed in the auction. An early book auction ordinance from the university city of Leipzig (1680) stipulates that the books must be arranged

\footnotetext{
15 On this sociological concept, and how this can be applied to history to better understand social order in the early modern period: RUDOLF SCHLÖGL, 'Politik beobachten: Öffentlichkeit und Medien in der Frühen Neuzeit,' Zeitschrift für Historische Forschung 35 (2008): 581-616.

16 WALL, 'The English Auction.'
} 
according to the order' of the catalogue and that the auctioneer had to announce 'the lot number [...] aloud. ${ }^{17}$ Similarly, a book auction decree from the university city of Halle (1704) states that books should be presented 'aloud and audibly,' in the order given in the catalogue. Later, regulations on book auctions explicitly demanded that the proceedings be documented, listing the highest bid and the buyer; the registration of this sort of information required an interleaved auction catalogue (see next paragraph). ${ }^{18}$

However, debates over such procedural rules and the extent to which these limited the auctioneers' rights can be found well into the eighteenth century. After all, by deliberately departing from the sequential method, auctioneers tried to keep visitors interested in the auction itself (otherwise, before attending the auction, the audience would wait until the objects for which they wished to bid were being sold). Such flexibility occurred, for example, when the estate of Clemens August of Bavaria (1700-1761), prince-elector of Cologne, was sold in 1764. The variety of items on offer ranged from livestock (such as dogs and horses), jewels and porcelain, to paintings and other art objects. In this specific case, the auctioneer sold the paintings in alternation with other artistic items. It is very likely that the auction was deliberately staged as such, in order to promote some objects as highlights of the event. ${ }^{19}$ And in the book trade too, the debate over the auctioneers' right to freely decide how to organise an auction continued into the eighteenth century, despite the decrees stipulating the contrary. ${ }^{20}$ However, in the course of the eighteenth century, auction catalogues provided the structure for auctions and guided the social interaction.

The significance of catalogues for social interaction can be found on other levels too: the texts indicate the names of agents offering to participate in an auction as mediators. The catalogues were thus a form of pre-structured, informal communication, as they were only suggestions to potential buyers and anyone could participate in the auction. Finally, they often contained instructions on how to play, or rather formally take part in, the 'game,' with regard to the scheduling, accepted currencies and payment requirements.

What was the reason for such a normative role? It is obvious that auction catalogues were a key factor to guaranteeing an auction's success. As a procedural handbook for the auction, the catalogue gave guidance, for example, on the collection on offer. It is also important to stress that the auction knew no class boundaries (at least theoretically), but rather levelled out social differences, or, as Cynthia Wall states with regard to late eighteenth-century English auctions: 'The public nature of the auction, as well as its formal structure of competitive bidding, created a spectacle of

17 Verordnung, Wie es mit Ver-Auctionirung derer Bücher oder Bibliotheken zu halten (Georg: Leipzig, 1680).

18 Auctions-Ordnung, Wornach bey der Hochlöblichen Friderichs-Universität Zu Halle Diejenigen so der Auction beywohnen, und entweder Bücher binein geben, oder daraus erkauffen, Sich zu richten haben. Publiciret d. 9. Febr. ([Halle]: Krebs, 1704).

19 Thomas Ketelsen and Tilmann von Stockhausen, Verzeichnis der verkauften Gemälde im deutschsprachigen Raum vor 1800, vol. 1 (a-hi) (Munich: Saur, 2002), 70.

${ }^{20}$ Hans Dieter GeBAuer, Bücherauktionen in Deutschland im 17. Jahrhundert (Bonn: Bouvier, 1981), 78. 
commercial and social dynamic [...]. ${ }^{21}$ Sources suggest that this led to concerns that the commerce could find itself destabilised by conflicts over class and status: the ordinance of Halle (1704), for instance, explicitly responds to this problem when it states that at an auction 'anyone has as much right as anyone else/ without regard to rank/ age or gender. ${ }^{22}$ And referring to the social differences that can be found in an early modern university city: 'The uneducated have the same right to attend the auction as scholars. ${ }^{23}$

Early modern observers thus paid a great deal of attention to the names and ranks of the people participating in an auction. This can be seen, for example, in an interleaved catalogue from 1798, which will be discussed in more detail in a later paragraph: the catalogue, inviting to a book auction held in Wolfenbüttel, records the highest bids and the buyers' names, including, as was common, their ranks and titles. Among these buyers were (noble) members of cathedral chapters, knights (lower nobility), courtiers, as well as other clerics, university professors and civil servants, even noble women took part. It was, therefore, a socially diverse community.

Significantly, the catalogue did not mention the many agents present; the author was not interested in the agents but in their clients and their bids. To him, the agents did not actively take part in the auction (which also makes this source interesting for research addressing the history of agents at auctions). The author does, however, make a difference between those bidders who were physically present and those who were not. The first group of bidders are recorded by their names. Those clients who sent an agent are referred to as living 'in' a specific town (such as 'Student Meyer in Gandersheim'). Clearly, the author's aim was to document the auction not only in economic terms, but also in social terms, by informing the readers about which person could claim to have won which bid. ${ }^{24}$

The public nature of the auction, the competitive bidding in a face-to-face setting and its principle that only one person could take the object home, were unique to auctions and made them very prone to conflict. In this context, object lists were not only products of early modern trading activities; their content also aimed to structure social interaction in various ways, thus contributing to the early modern auctions' political and social success.

\section{Market Guarantee}

Using such catalogues, book collectors, coin collectors, natural scientists and other individuals, as well as academies and universities, sought to assemble collections and to document, compare and classify objects circulating on the market in terms of their

\footnotetext{
21 WaLL, 'The English Auction,' 2.

22 Auctions-Ordnung 1704, \$ XXVI.

${ }^{23}$ Auctions-Ordnung 1704, § XXVI.

24 Systematisches Verzeichniß von Büchern, aus allen Theilen der Wissenschaften insbesondere bistorischen und in französischer Sprache, welche vom 17 ten August an ₹u Helmstädt öffentlich versteigert werden (Helmstedt: Kühnlin, 1789), Herzog August Bibliothek Wolfenbüttel, DE (HAB henceforth): H: Q 421.4 Helmst., digitally available: http:/ / diglib.hab.de/drucke/q-421-4f-helmst/start.htm (accessed September 1, 2020).
} 
type, provenance and economic value. The owners of collections or those wishing to sell them used catalogues to market them. For example, they gave long introductions to their collections and to the models used to assemble, arrange and describe the objects, as well as providing information on the social networks that had influenced and supported them. The sellers also used auction catalogues to spread their biographical information, and so they also served as memorials. ${ }^{25}$

One reason why auction catalogues were used to convey so much (paratextual) information was that these object lists circulated freely and in an increasingly large market. The auction served as a multiplier for such textual self-representations. At the same time, the auction as a trade business was important for how the readers thought about the content of an auction catalogue, in terms of its credibility. It should be emphasised again that auctions were not a socially exclusive, restrictive business, and that the dissemination of the catalogues could not be controlled. Therefore, the auction was a market-based system. To be true, the commercial aspect did not prevent traders from circulating misleading descriptions: according to one anecdote, the Dutch classical philologist Isaac Vossius (1618-1689) wrote an auction catalogue in which he promoted a small, insignificant tract with the lurid statement that it contained mathematical proof that the pope was an antichrist. Based solely on this description, the book was sold at auction for a much higher price than expected. ${ }^{26}$ However, due to the nature of the auction as open, not socially exclusive commerce, it was generally accepted that it was market-regulated (i.e., by the buyers who read the catalogues, circulated them, took part in auctions and bought items, or, in the event of fraud, turned their backs on them). The market-based setting created a framework in which auction catalogue readers were led to believe that false or misleading descriptions could at least not circulate en masse. Thus, the auction is yet another field in which early modern commerce contributed to the transmission of knowledge according to its own logic; in this case, the market in a sense vouched for the general credibility of the object descriptions. ${ }^{27}$ In other words, the value of the catalogue as an influential order of knowledge was rooted in the social and commercial interaction at auctions.

\section{Interleaved Auction Catalogues: Used Catalogues as a Source for Exploring Social Interaction}

Perhaps the most descriptive way to explore printed documents as intermedial objects in social interaction is to take a closer look at used auction catalogues and the material traces that can be found in individual copies. Recent scholarship on the history of knowledge has paid much attention to the appropriation of books through the inscription of manuscript marginalia and similar iconic and paralinguistic components

25 On book catalogues: WAlsby, 'Book Lists,' 10; Blom, Jagersma and ReBoul, 'Printed Private Library Catalogues,' 252 and 258.

26 AsTRID C. BALSEM, 'Collecting the Ultimate Scholar's Library: The Bibliotheca Vossiana,' in Isaac Vossius (1618-1689) between Science and Scholarship, eds ERIC JORINK and DIRK VAN MIERT (Leiden [u.a.]: Brill, 2012), 281-309. For further examples: Wall, 'The English Auction,' 11.

27 Dániel Margócsy, Commercial Visions: Science, Trade, and Visual Culture in the Dutch Golden Age (Chicago, IL: University of Chicago Press, 2014). 
- commentaries, notes, underlining, signs and sketches. Indeed, these marginalia provide information on the knowledge and understandings of individual readers or writers, changes in visual designs and the social interaction that could be had with and through a book.

Research on the practice of binding additional, blank sheets for the purpose of commentary between the printed pages of individual working copies of a text is still in its infancy. Whereas the term interleaving or interfoliate is used in English, other languages make a more specific distinction between the practice of interspersing in general (adding various blank sheets, in diverse places) and interleaving with one white sheet per printed page (doorschoten in Dutch or durchschossen in German) ${ }^{28}$ Finished printed texts could be relatively easily augmented by extra pages. As is well known, prints were usually sold unbound or only very rudimentarily bound together with threads. The interleaving changed the books' appearance considerably, not only as regards their size. It was also not uncommon for the selected leaves to have a different, larger format.
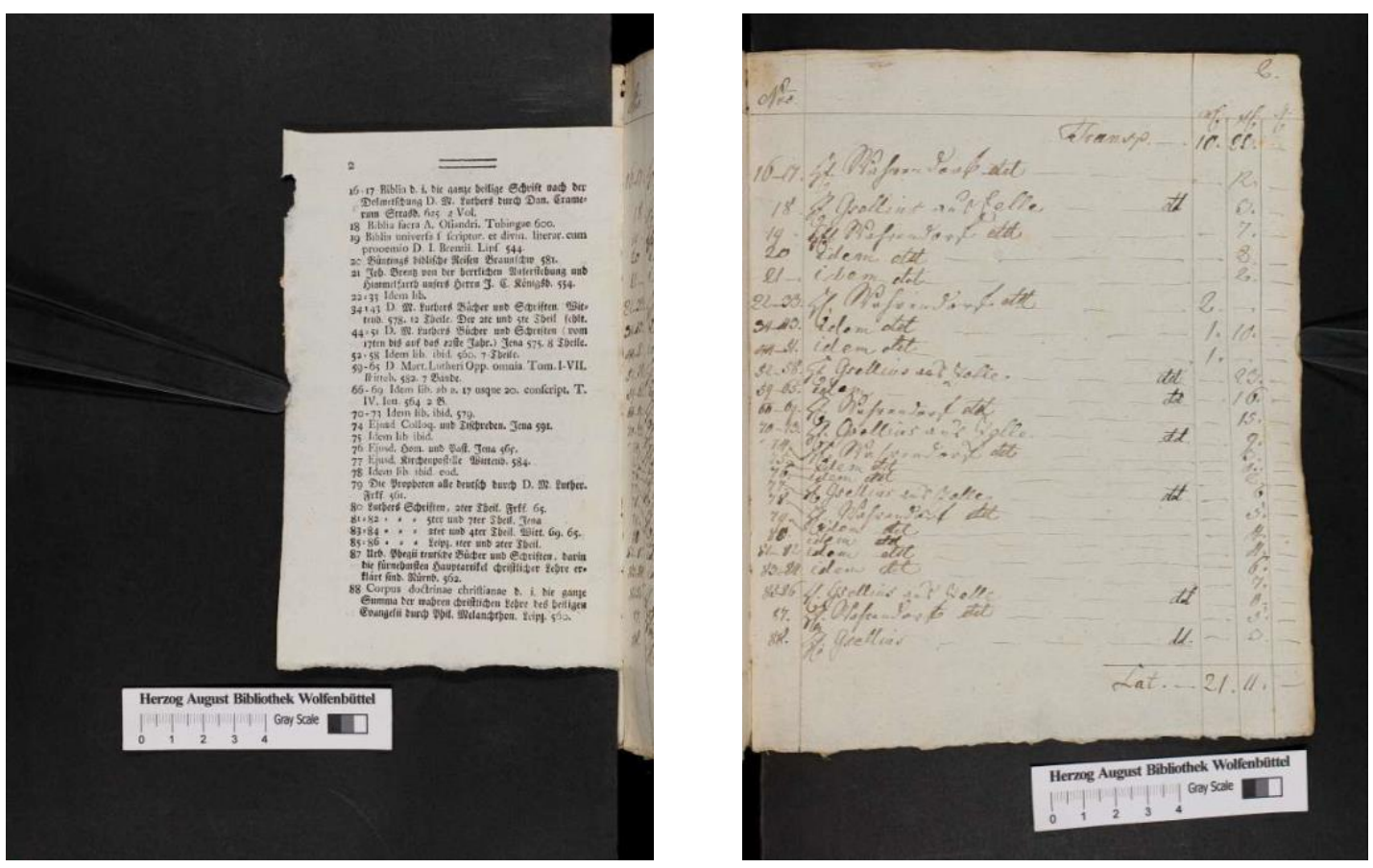

Figure 2: Binding of an auction catalogue: format differences between the printed and interleaved pages, Systematisches Verzeichniß von Büchern, aus allen Theilen der Wissenschaften insbesondere historischen (Helmstädt: Kühnlin, 1789), pp. 12 (2), 13, Herzog August Bibliothek, Wolfenbüttel, H: Q 421.4 Helmst., http://diglib.hab.de/drucke/q-4214f-helmst/start.htm.

28 On the German definition: Arndt Brendecke, 'Durchschossene Exemplare. Über eine Schnittstelle zwischen Handschrift und Druck,' Archiv für Geschichte des Buchwesens 59 (2005): 91-105. 
Library catalogues suggest that this practice became increasingly popular in the course of the early modern period. In the seventeenth and eighteenth centuries, publishers offered texts in simple and interleaved formats. A rare books library, the Herzog August Bibliothek in Germany, holds over 800 interleaved copies from the sixteenth to the eighteenth centuries, including calendars, emblem books and textbooks. It is assumed that this practice reached a peak at the end of the eighteenth century, when engraved portraits on blank sheets were also pasted in (a practice known as grangerising). The initial research on interleaved books focused primarily on the writers' knowledge. ${ }^{29}$ In 2006, Anne C. Henry expanded the focus in an essay on 'blank' emblems in novels. Moving beyond a marginalia-centred approach, she analyses the interplay of the printed and blank sheet in terms of visual strategies and discusses the role that interspersed texts play in making up our world. Using real and metaphorical 'blank sheets' as examples, she argues that the interplay of print and manuscript can form its own narrative. ${ }^{30}$ In recent years, other contributions have turned to epistemic practices too. By aligning avenues of inquiry from the history of science and book history, they scrutinise the juxtaposition of print and manuscript and assess how this advanced knowledge. As Arndt Brendecke, who has analysed interleaved historical tables, puts it, knowledge is not constituted in one medium alone, but always in intertextual and cross-medial interplay. ${ }^{31}$

Auction catalogues have so far received little to no attention in this context. Anne C. Henry mentions 'sales catalogues where prices are added to the blank sheets' in the 'work-related interleaves' category, which she rightly criticises but does not go into any further detail; her interest lies in 'blank' literature. ${ }^{32}$ Admittedly, a cursory glance at auction catalogues reveals a rather monotonous appearance; most catalogues only contain names and prices, which may explain why interleaved copies and their story in the history of trade and knowledge has so far been neglected by modern scholarship.

\section{Marginalia in Auction Catalogues and Advancing Knowledge through Interleaved Catalogues}

Before dealing with the special intermedial connection between interleaved catalogues and the social setting of an auction, a few preliminary remarks on the appropriation of auction catalogues are necessary. As one would expect given the wealth of information provided by these sources, many surviving auction catalogues contain marginal notes. ${ }^{33} \mathrm{~A}$ case in point is a widely used book catalogue that was

${ }^{29}$ HeAther J. JaCKsON, Marginalia: Readers Writing in Books (New Haven, CT; London: Yale University Press, 2001), 34.

30 Anne C. Henry, 'Blank Emblems: The Vacant Page, the Interleaved Book and the Eighteenthcentury Novel,' Word and Image 22 (2006): 363-71.

31 BrendeCKE, 'Durchschossene Exemplare,' 64. See also PETRA Feuerstein-HerZ, 'Seitenwechsel. Handschrift und Druck in durchschossenen Buchexemplaren der frühen Neuzeit,' Materialität: Von Blättern und Seiten 9 (2019): 19-26.

32 HENRY, 'Blank Emblems,' 365.

33 On the dissemination of auction catalogues in general see ANDREW PETTEGREE and ARTHUR DER WeDuWEN, The Bookshop of the World: Making and Trading Books in the Dutch Golden Age (New Haven, CT; London: Yale University Press, 2019). 
printed to sell a book collection assembled by a certain religious figure named Cardinal Du Bois (1656-1723). The auction, with its almost 30,000 lot numbers, lasted about two months and is considered the largest of its time. Of the more than 60 copies of the catalogue known today, about a quarter contain marginalia. ${ }^{34}$ Many art sales catalogues with and without annotations have survived too, in more than ten, twenty or in some cases thirty copies. ${ }^{35}$

As mentioned above, auction catalogues were also equipped with blank pages for the purpose of commentary: we know of copies containing mere blank sheets to which the planned commentary was not added (even several copies for one work) as well as copies with interspersed pages that contain a rudimentary commentary only. A rare example, preserved by the Herzog August Bibliothek, of an interleaved book sales catalogue with a commentary on the actual text deals with the bibliographical data. ${ }^{36}$ However, in the vast majority of cases, the writing space was not created to comment on the individual lots or the history of the collection, but to record the auction, that is, the buyers and prices of the respective lots. For the dealers, the blank sheets were an instrument to counteract the transitory nature of the economically and socially significant event. As the bidders usually paid at the end of the auction, it was important for the dealers to keep exact records of the action in order to be able to successfully enforce financial claims. The high density of marginalia in interleaved copies also proves that a number of people, whether observers, readers or copyists, were interested in capturing this brief snapshot of a publicly conducted trading transaction. After all, it offered the rare opportunity to trace which persons had bought which object and at what price - and thus to acquire not only information on individual lot numbers but also on the object, market and buyer in relational terms too. To be more specific: the auction itself, and the interleaved catalogues even more so, enabled observers at auctions and readers of the catalogues to determine the objects' value. As the objects were sold one after the other, auctions told their audiences which groups of objects fetched particularly good prices (and which did not). In other words, the different price levels were made visible, which, as the research has shown, promoted the formation of taste. ${ }^{37}$

Besides this, the retail business and text could serve as sources providing information on buyer behaviour in terms of which items were bought by which different social groups (e.g., academics, courtiers and aristocrats). ${ }^{38}$ Many user traces

${ }_{34}$ Bibliotheca Duboisiana ou Catalogue De L a Bibliotheque De feu son Eminence Monseigneur le Cardinal Du Bois (The Hague: Johannes Swart \& Pieter de Hondt, 1725), see, for example, data in Book Sales Catalogues Online (BSCO) - Book Auctioning in the Dutch Republic, ca. 1500-ca. 1800, advisor: Brill (Leiden and Boston: Brill, 2015), https:// primarysources.brillonline.com/browse/book-sales-catalogues-online, s.v. "Bibliotheca Duboisiana" (accessed September 1, 2020).

${ }^{35}$ Frits LugTs, Répertoire des Catalogues de Ventes Publiques intéressant l'Art ou la Curiosité, 1, Première période, vers 1600-1825 (La Haye, 1937).

${ }^{36}$ Catalogus librorum maximam partem nitidissime compactorum rarissimorumque quibus dum viveret usus est Gottfrid. Leonardus Baudis (Leipzig: Winckler, [1740]).

${ }^{37}$ See, among others, DE MUNCK and LYNA, eds, Concepts of $V$ alue.

38 With regard to the social relevance of auctions see also WALL, 'The English Auction.' 
contained close to the buyers' names in the catalogues show how important catalogues were as a medium for generating knowledge on certain buyers in relation to others, even in retrospect. The catalogues enabled early modern observers, readers and copiers to compare not only which individuals, but also which collectives, primarily purchased which objects and at what price. This is shown by the above-mentioned catalogue from 1798, which records the bids and the buyer names, including their ranks and titles: abbots, university professors, members of cathedral chapters, knights (lower nobility), courtiers and civil servants among others. ${ }^{39}$ On the basis of the data contained in the catalogues, readers could regroup and reorder information on buyers. The catalogues thus opened up ways of producing new knowledge in terms of the social dimension of trade.

\section{Interleaved Interaction}

Whereas interleaved prints in general have been described as witnesses of the early modern experience of both reading and writing, auction catalogues can be treated as an intermedial interplay of printing, social interaction and the handwritten accounting or documentation of trade. This interplay becomes apparent in another, so far neglected group of hybrid auction catalogues: interleaved copies containing the auction minutes, that is, the buyers' names and highest bids.

As indicated, eighteenth-century Germany saw a rise in regulations designed to structure auctions and make them transparent. In the case of book auctions, this effort was related to censorship. In general, the decrees also aimed to prevent fraud (on the part of the auctioneers as well as the bidders) and, not least, as will be discussed herein, to guarantee social openness in this face-to-face setting that produced 'winners' and 'losers,' (ideally) irrespective of the person and his rank. Economists of the time, for instance, welcomed auctions as a good thing, as long as they were open to all and the objects were sold at the highest bid; auctions were seen as a way to promote the circulation of goods and money, and, ultimately, not only to boost the economy but also to change society by enabling social mobility. In Prussia, this led to a decree (1756) which appointed an official auctioneer. One of his key duties was to record the bidders' names and bids to ensure, among other things, that there would be no reason for contestation afterwards, as there was a tendency for bidders to dispute the results and the auction to end in turmoil (a subject that was dealt with in almost all of the ordinances). ${ }^{40}$

Another item introduced to auctions was the interleaved auction catalogue, which can be found in auction orders of the University of Halle (1704), the University

39 Systematisches Verzeichniß.

40 'No. XLIII. Reglement und Instruction für die Auctionatoren. De Dato Berlin, den 12ten April 1756,' in Novum Corpus Constitutionum Prussico-Brandenburgensium Praecipue Marchicarum ... von 1756 ... und 1760, ed. Christian OtTo Mylius, vol. 2 (Berlin: Königlich Preuß. Akad. der Wiss., 1760), 58-68. 
of Göttingen (1737) and the City of Nuremberg (1795), to name but a few. ${ }^{41}$ These decrees relate primarily to book auctions, which were more regulated than art and household goods sales. They did, however, also serve as models for other auctions. ${ }^{42}$
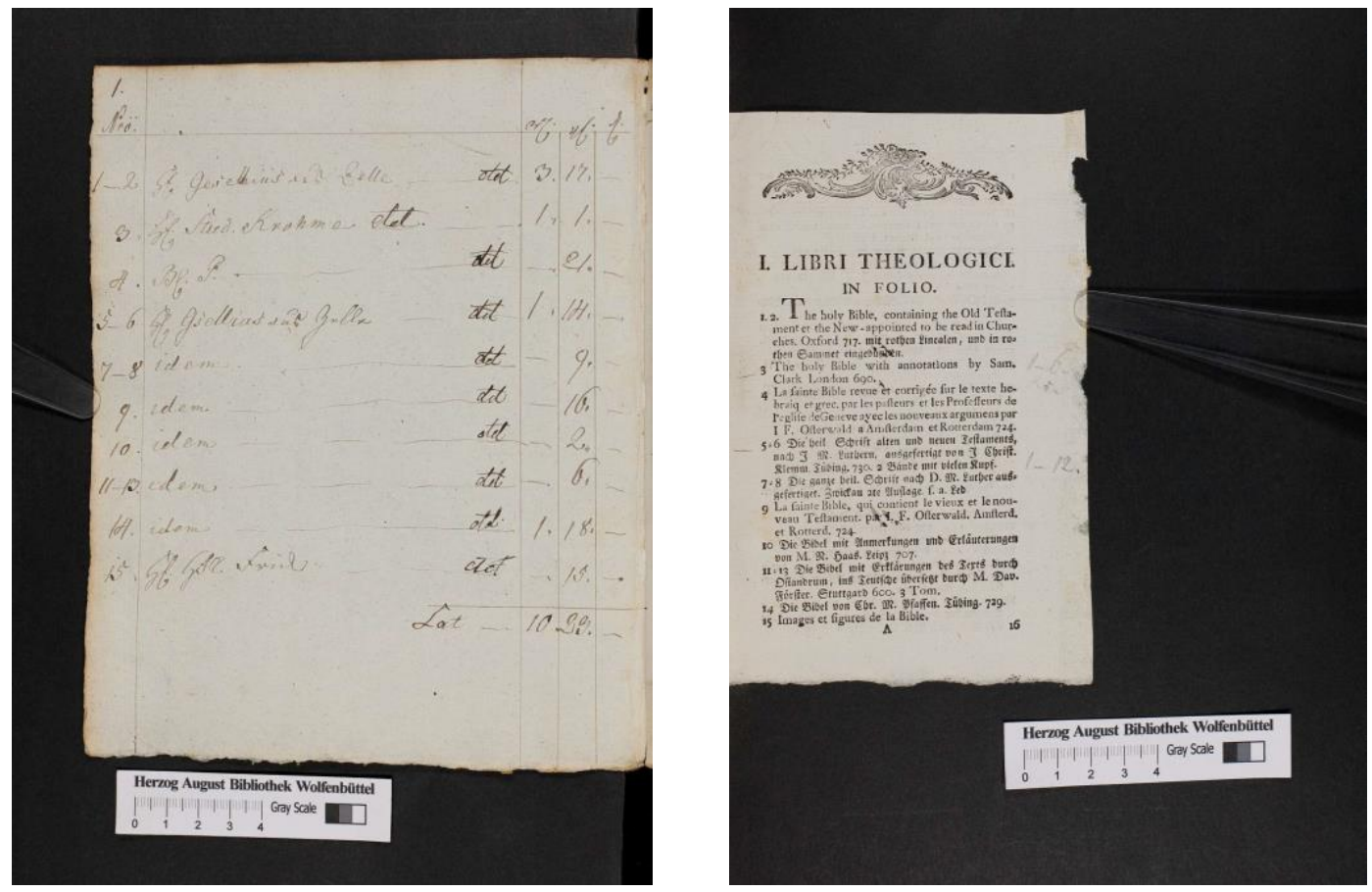

Figure 3: Inside an interleaved auction catalogue: the printed list and auction minutes. Systematisches Verzeichniß von Büchern, aus allen Theilen der Wissenschaften insbesondere historischen (Helmstädt: Kühnlin, 1789), pp. 10, 11, Herzog August Bibliothek, Wolfenbüttel, H: Q 421.4 ${ }^{\circ}$ Helmst., http://diglib.hab.de/drucke/q-421-4fhelmst/start.htm.

A closer look at these hybrid catalogues reveals that they can easily be identified by the different size of the interleaved writing paper. In many cases, the manuscript leaves also have their own pagination. There are a few pitfalls to consider when analysing interleaved auction catalogues. For example, as many of these manuscripts are unfortunately not signed by the authors, it is difficult to establish whether they were created for personal use (as informal or personal records), or for official use. A case in point is a rare copy from the seventeenth century of an auction catalogue for the private collection of Herman Conring, known for his significant works on German medicine, politics and law

${ }^{41}$ Göttingen 1737; Verordnung Wie es mit denen Bücher-Auctionen zu Göttingen, zu halten ([Hannover], 1737); ERNST L. HAUSWEDELL, 'Auktionsordnung der Stadt Nürnberg von 1770,' in Bibliothek, Buch, Geschichte, ed. GÜNTHER PFLUG (Frankfurt am Main: Klostermann, 1977), 241-48.

42 As can been seen for example regarding the city of Gotha's auction decree: 'Vorschrift, welche bey denen in allhiesiger Residenz-Stadt Gotha vorzunehmenden Auctionen zu beobachten ist, vom 19ten Martii 1783,' Zusatz zum ersten Theile der neuen Beyfugen zur Landes-Ordnung, ed. Herzogl. Sächs. Regierung, vol. 6 (Gotha, [1804]). 
(1694). This catalogue is interleaved with large sheets of paper, containing the names of more than sixty buyers, among these professors from the nearby university of Helmstedt, officials from nearby cities, and other individuals from the Wolfenbüttel court and territorial administration. ${ }^{43}$ The neat handwriting and layout suggest that the manuscript was not created during the actual auction but rather ex post, most likely by the auctioneer as a report for Conring's heirs who sold the collection after his death.

In the eighteenth century, this practice became more common, and increasingly, the documenting took place during the actual event. A manuscript bound in a catalogue called the 'Systematic Book List from All Fields of Science,' also kept in Wolfenbüttel and published in 1789, contains corrections made to the text in a hasty script, giving a better impression of the dynamic nature of an auction. ${ }^{44}$ The collection, with about 9,000 lot numbers, is listed on 369 pages. The total number of pages is 770 , because it contains an extra page in a larger format after each printed sheet. As is also the case of the Conring catalogue copy, we do not know for sure who created this hybrid object list or who recorded the minutes. Most likely it was the auctioneer, as the record also notes that the bids were paid. We know for sure that this was the case regarding another hybrid catalogue, which was put together and signed by an appointed officer in charge of auctioning the collection of a deceased lawyer. ${ }^{45}$

Other copies seem to be of a more private, individual nature. A case in point is a copy of a catalogue from 1737, which, like its more official counterparts, records the bidders' names and the highest bids. In contrast, however, it does not include information on whether the bids were paid and instead deviates from the normal pattern. Its main interest lies in the bidders and the bids. What is more, it explores the behaviour of one particular bidder, a university professor at the university of Helmstedt, Johann Nikolaus Frobese, in detail (the author underlines his name throughout the copy). Frobese had only recently been awarded a chair in metaphysics, and ranked at the lowest end of the professorial scale. He still had to work his way up in the academic order, which could explain his eagerness to buy books and the interest the author (the same Frobese perhaps?) shows in this ambition. ${ }^{46}$

A further difficulty concerns the structure of the medium as such. In most cases we cannot say with certainty whether the blank sheets were inserted before or after the

43 Catalogus Bibliothecae Conringianae (Helmstedt: Hamm, 1694), HAB: H: Q 42.4 Helmst., digitally available: http://diglib.hab.de/drucke/q-42-4f-helmst/start.htm (accessed September 1, 2020); on this collection see PAUl RAABE, 'Die Bibliotheca Conringiana,' in Hermann Conring (1606-1681). Beiträge zur Leben und Werk, ed. MiCHAEL STOLLEIS (Berlin: Duncker \& Humblot, 1983), 413-34.

44 Systematisches Verzeichniß.

45 Bibliotheca Kochiana: Wolfenbuttelae D. XXXI. Avgusti MDCCLXVII. Lege Avctionis Vendenda; Accedit Appendix Librorvm et Nvmismatvm ([Wolfenbüttel]: Literis I. W. Bindseil, [1767]), HAB: Cod. Guelf. 171 Noviss. $2^{\circ}$.

${ }^{46}$ M: Bc 96 Johann Gothofried Lakemacheri Prof. LL. Oriental. in Acad. Julia Quondam Ordinarii et Celeberrimi Selecta Bibliotheca Philologica, Libros in Qualibet Philologiae Parte Insigniores Aeque ac Rariores Complectens; Quae Publicae Auctionis Ritu Helmstadii Anno MDCCXXXVII. Die XIX. Januarii et Sequentibus Horis ... Pro Parata Pecunia interplus Licitantes Distrahetur (Helmstedt: Drimborn, 1736). HAB: M: Bc 1182. Digitally available: http://diglib.hab.de/drucke/bc-1182/start.htm (accessed September 1, 2020). 
auction. Some regulations stipulated that the interleaved copies had to be prepared before the auction. According to rules in Göttingen, for instance, the secretary directly recorded the names of the bidders and highest bids in an interleaved copy of the catalogue. However, the extra pagination of the minutes seems to show the opposite. It rather indicates that, to begin with, the minutes were individual objects and were merged with the printed text into one medium at a later stage; this was clearly more practical for the person who took the minutes, as he (or, less likely, she) could lay the paper flat out in front of him (her).

Why were auctions recorded in this sort of catalogue? How could this new method of merging print and manuscript have contributed to structuring the auction and guaranteeing transparency and equality in this socially diverse and, due to its public nature, performative setting? Besides serving as a way to document, collect and constitute knowledge on buyers, interleaved auction catalogues were functional in that they forced the auctioneers and bidders to follow procedural rules. As I have mentioned, we cannot say with certainty that the interleaved copies were used at the actual auction. However, with regard to their organisational principles, it did not make a big difference whether or not the interleaved copy had been prepared previously. What was crucial for the procedure was that the catalogues would at some point (if not during the auction then later) serve as an archive. In order for this to work, two preconditions had to be met: Firstly, the print had to be available to the person taking the minutes so that he knew which lot numbers to document on which page (so that the minutes' layout would fit that of the print). Secondly, the given order in the catalogue had to be strictly adhered to; any deviation from it would have made it impossible for the auctioneer or secretary to record the bids. Thus, this new method put the catalogue at the centre of the auction and turned it into its script, thereby limiting how the objects could be sold and the way in which the attendants could interact. This did not only impose restrictions on the auctioneers, who could not freely choose which objects to present when or respond to the dynamics of the face-to-face setting. It also reduced the bidders' chances to refuse bids they did not - or, in view of their ranks - could not accept by claiming procedural irregularities.

This is the final development towards defining the catalogue as a 'script.' As a result, the auction, a socially dynamic event, was placed on a firmer footing. These hybrid prints also raise questions that pertain to the social and cultural history of the auction in general, which can only be hinted at herein. In line with the scholarship on interleaved rare books, I would argue that the interplay of print and manuscript creates its own epistemic perspective or narrative. The auction minutes provide evidence for the catalogues, in the sense that their contents gain greater credibility; the buyers' names and prices make these catalogues particularly 'trustworthy' trade documents. But, more to the point of this paper, how did the interplay impact the perception of the public nature of auctions? In accordance with Cynthia Wall's claim that eighteenth-century English auctions exhibited 'the changing possibilities of social boundaries,' one could argue that the documentation and notes kept of the bidders' names, interlinked with the auction 
catalogue, shaped the social and cultural power of auctions as spectacles that could potentially change the social order. ${ }^{47}$

Though further research is needed on when these hybrids were used and by whom, their relevance is undisputable. This can be shown, for example, by the fact that in the early modern period auction catalogues were seen as important sources for academic teaching; both the catalogues and the marginalia they contained were widely discussed in journals of the time. ${ }^{48}$ These sources suggest that due to the social openness of auctions, these catalogues were not only considered to be easily accessible but were also deemed 'public' sources, just waiting to be exploited in terms of the object knowledge they provided. For instance, in a journal article from 1783 on book prices and how best to contain what the author considered the growing greed among booksellers, price lists recorded in auction catalogues were introduced as an overlooked source and solution to this economic and social problem. According to the author, such records could be used to establish an average book price for every book ever to have been published, thereby largely ignoring any differences in size, edition or other individual features a book might have. The writer's two main assertions were that auction catalogues containing such data were easily accessible (although it is not said where) and that, due to their competitive nature, auctions rarely sold overpriced objects. According to this argumentation, the article claimed that the model could also be used to assess general education or erudition (Gelehrsamkeit), as it provided comparable data of how much people of a certain region were prepared to pay for any given book.

In this argumentation, bizarre as it may seem today, the author treated auctions, at large, as open market sales that guaranteed fair trade. Neither the social conflicts that the catalogues initially aimed to limit, nor the social context that impacted both the bidding process and the prices at which objects were sold, were considered in this lateeighteenth-century model, but the trade data, produced by a supposedly public market. ${ }^{49}$ On the whole, this model shows the relevance that was attributed to these hybrid auction catalogues for social and economic questions that could lie beyond the object trade. At the same time, it contributed both to shaping a view of the auction as socially inclusive and as culturally powerful in terms of its potential to change societies, and to disseminating an understanding of the social interaction that took place there.

Indeed, these hybrid catalogues also raise questions pertaining to the social interaction that took place at auctions, for example: What new concepts did auctioneers invent to market things when, due to an increase in rules regulating auctions, these printed documents were upgraded to scripts and functioned as templates for the auction? Or, in terms of the catalogue's position in the auction business: What effect did it have

47 WaLl, 'The English Auction,' 6.

48 Gebauer, Bücherauktionen, 68 and 81. With regard to art catalogues: STOCKHAUSEN, 'Formen des Ordnens,' 99; FLEMMING SCHOCK, 'Bücher in Bewegung. Bibliotheken und Buchauktionen in den gelehrten Journalen des 18. Jahrhunderts,' in Wissen in Bewegung. Gelehrte Journale, Debatten und der Buchhandel der Aufklärung, ed. KATRIN LÖFFLER (Stuttgart: Franz Steiner Verlag, 2020), 75-90.

49 'Ueber die Kenntniß der mittlern Auctionspreise von Büchern,' Wittenbergisches Wochenblatt 12 (March, 28, 1783), 89-94 and 14 (Paril, 11, 1783): 105-108. 
on these printed documents that the conditions for holding auctions had changed? These documents indicate that their potential use as scripts for social interaction at auctions (for the bidding procedure) was taken into account when they were made. This can be seen in the order of the page breaks: in many (especially later) catalogues every new page starts with a new lot number. Each printed page thus forms a textual unit. In a sense, this is a concession to those who wished to fill the printed copies with extra sheets for individual use. Thus, interleaved catalogues allow us to refocus attention on intersections between different media (print and manuscript). At the same time, these hybrids call for research on this interplay which takes into account the social interaction that accompanied and produced it.

\section{Conclusion}

This paper advocates an approach that includes the praxeological dimension of auctions in the study of auction catalogues. It argues that, in order to better understand their characteristics, we need to look more closely at the specific social setting at which they were aimed, which, in turn, affected how they were used and what they tell us about the objects. The first paragraph serves as a framework for this approach: as explained in detail with regard to the fictional dimension of auction catalogues, the lot number descriptions often appeared to be a close account of the former life of a collection (the former practice of collecting) and did not necessarily aim to provide a comprehensive overview of the collection. Also, though not initially intended to be the heart of the actual event, auction catalogues gradually began to serve as 'scripts,' structuring and enabling the social interaction in various ways (in a performative role). Finally, on a more general level, this contribution considers how the open market and the social interaction at auctions impacted the dissemination of these orders of knowledge. A closer look at interleaved auction catalogues not only confirms the complex relationship between catalogue and event, by explaining in more detail how (and why) the auction catalogue gradually became a template for auctions, it also shows the potential for further research on how catalogues in turn responded to changes in terms of their make-up.

Thus, the aim of my essay is to suggest an approach to auction catalogues that looks beyond object provenance, trade routes and market data. By refocusing on these sources as usable and used objects, it draws attention to their relevance for social interaction and, in turn, their origin in trade activities. On a more general level, this contribution also seeks to rethink the (mercantile) history of knowledge, going beyond an inner view to trace its social dimensions. In recent years, scholars have expanded their focus on the making of knowledge, in terms of the material preconditions for it (printing, miscellaneous orders, etc.) on the one hand, and social ties and networks on the other. This is furthered by attempting to embed these practices in social and commercial interaction. In order to fully understand early modern (object) knowledge and trade, we need to look more closely at how they were shaped by cross-media interplay. 